\title{
Evaluation of kidney abnormalities in mongrel dogs using clinical, ultrasonographical and biochemical examinations*
}

\author{
Ramazan GÖNENCI ${ }^{1}, \operatorname{Ramazan~DURGUT}^{2}$, Suat ERDOĞ ${ }^{3}{ }^{3}$, M. Enes ALTUĞ ${ }^{1}, \operatorname{Ramazan~BAL}^{4}$ \\ ${ }^{1}$ Departments of Surgery, ${ }^{2}$ Internal Medicine, ${ }^{3}$ Biochemistry, ${ }^{4}$ Physiology, Faculty of Veterinary Medicine, University of Mustafa \\ Kemal, Antakya
}

\begin{abstract}
Summary: In this study, 25 female and 15 male mongrel dogs, aged ranging from 1 to 7 years, were used. They were subjected to clinical, ultrasonographical and biochemical examinations. Ultrasonographically in 18 of the 40 dogs ( $45 \%)$, different kidney abnormalities were observed, whereas the other 22 dogs were found normal. Likewise, serum urea and creatinine levels were measured to be higher in the dogs with kidney abnormalitics. Serum creatinine clearance estimated using the Cockroft-Gault equation was exceeding the physiological range. In conclusion, for mongrel dogs ultrasonographic examination, measurements of serum urea nitrogen (BUN) and creatinine, and calculation of serum creatinine clearance using the Cockroft-Gault equation might be useful to diagnose early kidney abnormalities.
\end{abstract}

Key words: Biochemical analysis, dog, kidney, ultrasonography

\section{Melez köpeklerde böbrek bozukluklarının ultrasonografi ve biyokimyasal muayenelerle değerlendirilmesi}

Özet: Bu çalışmada yaşları 1-7 arasında değişen 25 dişi ve 15 erkek melez köpek kullanıldı. Köpekler her iki böbrek yönünden klinik, ultrasonografik ve biyokimyasal yönden muayene edildi. Ultrasonografide kırk köpeğin 18 'inde (\%45) farklı böbrek anormallikleri gözlenirken diğer 22 köpeğin normal olduğu belirlendi. Ayrıca, serum üre ve kreatinin düzeyi ile Cockroft-Gault denklemini kullanarak belirlenen serum kreatinin klirensi, böbrek anormallił̧i belirlenen bu köpeklerde fizyolojik sınırların istündeydi. Sonuç olarak, erken böbrek anormalliklerini tanımak için rutin olarak ultrasonografik muayenenin yapılması, serum üre ve kreatinin seviyelerinin ölçülmesi yanısıra Cockroft-Gault formülünü kullanarak serum kreatinin klirensinin düzenli olarak hesaplanmasınında faydalı olabillecełi kanısına varıldı.

Anahtar kelimeler: Biyokimyasal analiz, böbrek, köpek, ultrasonografi

\section{Introduction}

The kidneys are two of the most important organs in the body. Their essential function is to maintain the homeostasis, for instance, excreting waste products and toxic substances into urine, controlling the balance of acids or bases in the body $(6,16)$. Once started, a kidney disease is unstoppable; kidneys may eventually lose the ability to remove waste products and excess nutrients from the blood, which can ultimately lead to death $(2,3,7,15,16)$. Kidney diseases are not easily detectable, especially in its early stages. Serum creatinine and urea nitrogen levels are not changed until about three-fourths of kidney function is lost $(15,16)$. Ultrasonography is the most common modes for visualizing aberration in the number, size, and texture and position of the kidneys $(1,11,15,18)$ and related structures as well as the presence of mineralizing densities $(4,10,13,14)$. The clearance of endogenous creatinine has been used as a measure of glomerular filtration rate (GFR) since the $1940 \mathrm{~s}(5,8,12)$, which can be calculated with different methods using different parameters. Using Cockroft-Gault equation, it is possible to calculate creatinine clearance with sufficient accuracy, provided serum creatinine and the patients weight and age, as follows: creatinine clearance $=(140$-age [year] $\mathrm{x}$ (patient's weight $[\mathrm{kg}]$ ) $/ 72 \mathrm{x}$ (serum creatinine [mg/dl]), correcting serum creatinine to $1 \mathrm{mg} / \mathrm{dl}(5,8,12)$. The aim of this study was to investigate the incidence of kidney problems in mongrel dogs in Antakya province from March 2001 to March 2002 using clinical and ultrasonographical examinations, and calculating creatinine clearance.

\section{Materials and Methods}

For this study, 25 females and 15 males mongrel dogs, aged between 1 and 7 years, were evaluated between March 2001 and March 2002. They were

* This study was financially supported by University of Mustafa Kemal, Research Fund, Antakya (Project number: 01G 0202). 
subjected to clinical, ultrasonographical and biochemical examinations for the presence of kidney diseases or any other abnormalities. Following the generel examination, dogs were restrained in dorsal, and lateral recumbency and alcohool and ultrasonic coupling gel applied to the clipping skin for ultrasonography.

Ultrasonographic evaluation of kidneys and ureters was performed using a scanner $100 \mathrm{LC}$ Vet ultrasound machine (Pie Medical Equipment B.V., Philipsweg 6227 AJ Maastricht, The Netherlands) with a 5.0/7.5 mega-hertz (MHz) LA DF Vèt TRD (41460, 41518) ultrasonic transducer. Kidneys were examined in longitudinal, sagittal, and transversal planes. Images were recorded on a $1.44 \mathrm{MB}$ standard computer disc. Results were recorded for each dog at the time of examination as either negative or positive for the disease based on identifiable structure within the kidneys.

For biochemical evaluations, $10 \mathrm{ml}$ of blood samples were taken from the jugular vein, and sera were separated by centrifugation. Kidney function was evaluated by testing serum blood urea nitrogen (BUN), creatinine albumin, total protein and phosphate in AMS Autolab analyser using BMS kits. Serum creatinine clearance was calculated by the Cockroft-Gault equation as follows: Creatinine clearance $=(140$-age [year] $\mathrm{x}$ (patient's weight $[\mathrm{kg}]) / 72 \times($ serum creatinine $[\mathrm{mg} / \mathrm{dl}])$ $(5,8,12)$.

\section{Results}

In ultrasonography of 22 dogs, the longitudinal plane appeared bean-shaped. In the transverse section, the kidney was rounded. The renal medulla was anechoic and had several segments. The medulla and cortex were of

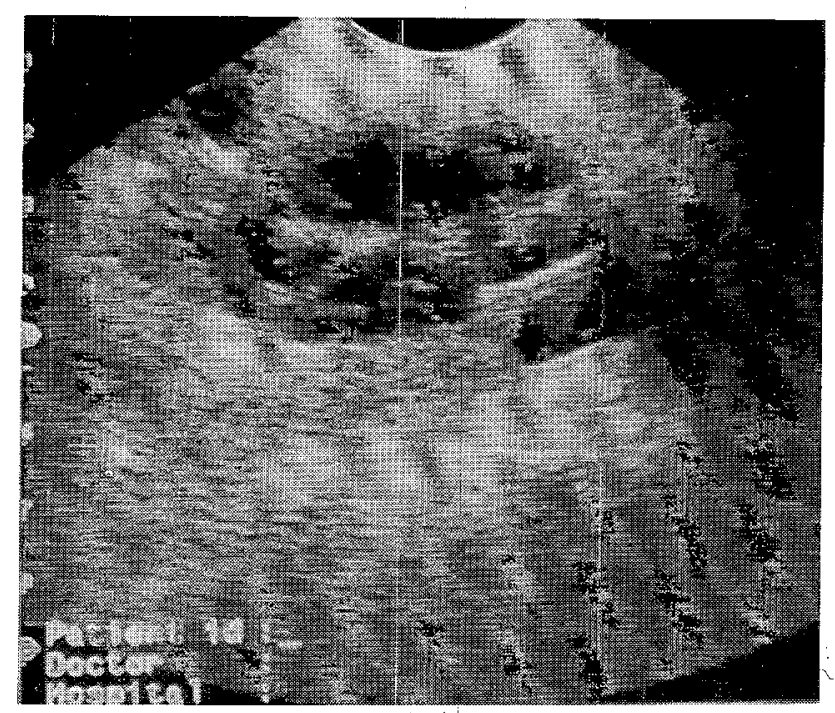

Figure 1. Ultrasonographic appearance of a mass with increased medullary echogenicity and reduced clarity of the corticomedullary junction. equal thickness. Blood urea nitrogen, creatinine, total protein, albumin, and phosphate were in normal reference ranges.

Clinical, ultrasonographical and biochemical examinations showed the presence of kidney abnormalities in 18 of the 40 dogs. Dorsal ultrasound (case no 1) image of right kidney in a dog showed a mass with increased medullary echogenicity and reduced clarity of the corticomedullary junction (Filgure 1). In two dogs (case no 2,3) a dilated anechoic pelvis with a dilated ureter was observed (Figure 2). A bright, echogenic line casting acoustic shadows was present at the corticomedullary junction in a dog (case no 4). Discrete, round, anechoic structures with gicep acoustic enhancements were seen, which were ranging in diameter from $1.8 \mathrm{~mm}$ to $3.5 \mathrm{~mm}$ in two dogs (Figure 3; case no $5,6)$. In a dog (case no 7 ), on the right kidney there were variable degrees of acoustic enhancements with more echogenicity, with a thick irregular wall (Figure 4). In two animals (case no 8,9 ), left kidneys were small and hyperechoic, loss of normal architecture with thinning of cortex were striking (Figure 5).

In four dogs (case no 10,11,12,13), diffuse increase in echogenicity were detected. In addition, loss of distinction between cortex and medulla were seen (Figure 6). Urinalyses of these animals indicated mild proteinuria, and low specific gravity (1005-1010). Stiff-legged gait, painful kidneys on palpation, less urine production, weakness and exercise intolerance and pale mucous membranes were observed in these three dogs.

In two animals (case no 14,15), pelvic dilatation and partial echogenicity in their left kidneys with enlarged and irregular architecture were the major findings (Figure

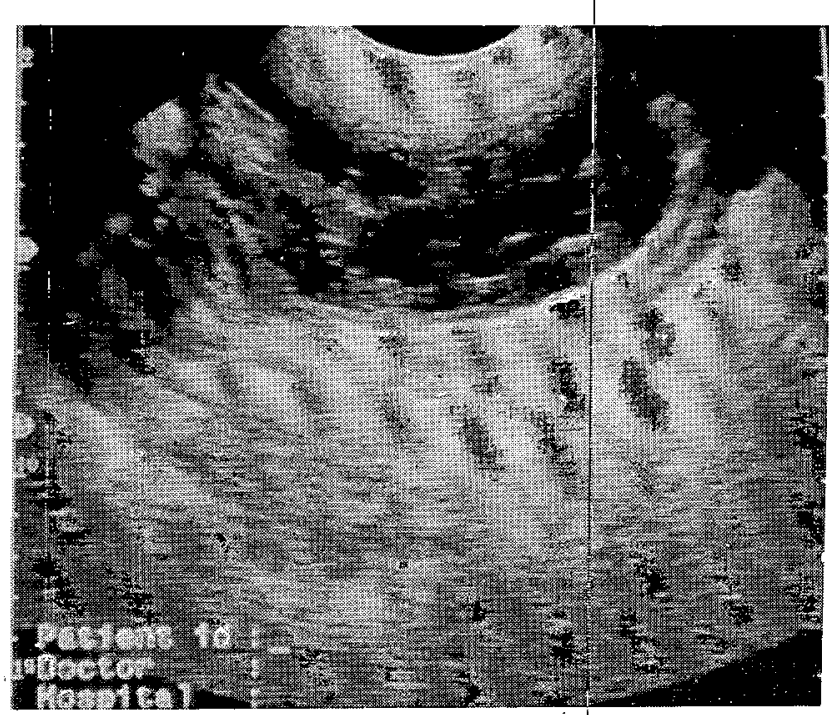

Figure 2. A dilated anechoic pelvis and ureters in ultrasonography. 


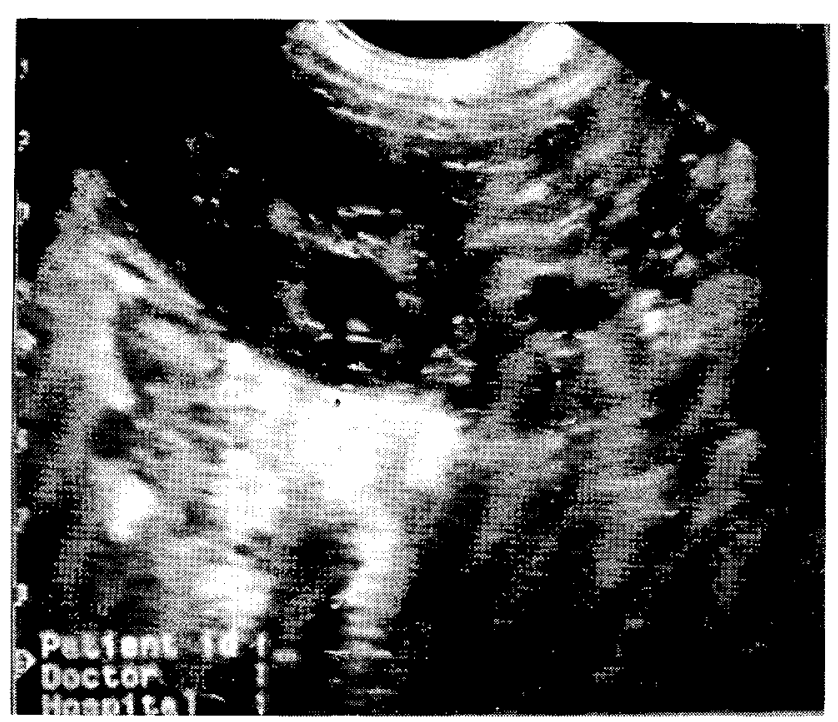

Figure 3. Ultratsonographic appearance of a discrete, round and anecheic viructure in a kidnev.

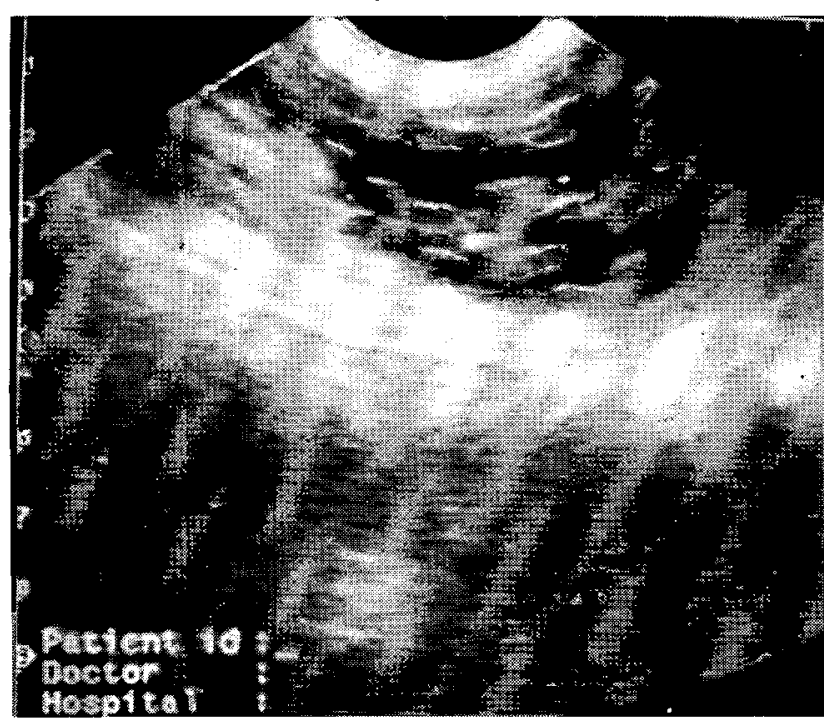

Figure 5. Small and hyperechoic appearances of a kidney with losis of normal archilecture and thinning of cortex in ultrissomeraphy.

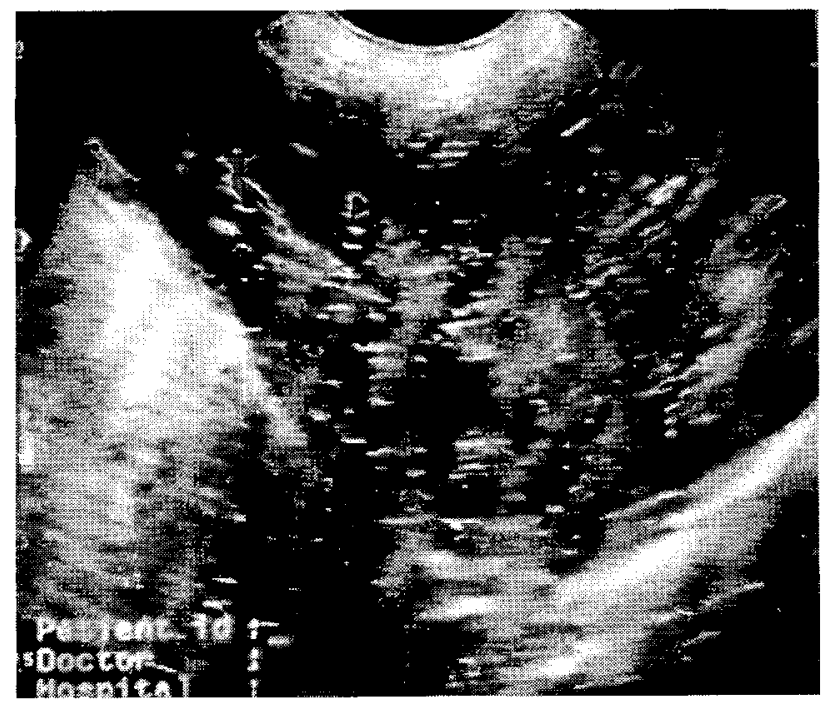

Figure 7. Pelvic dilatation and partial echogenicity with enlarged and irregular architecture in ultrasonography.

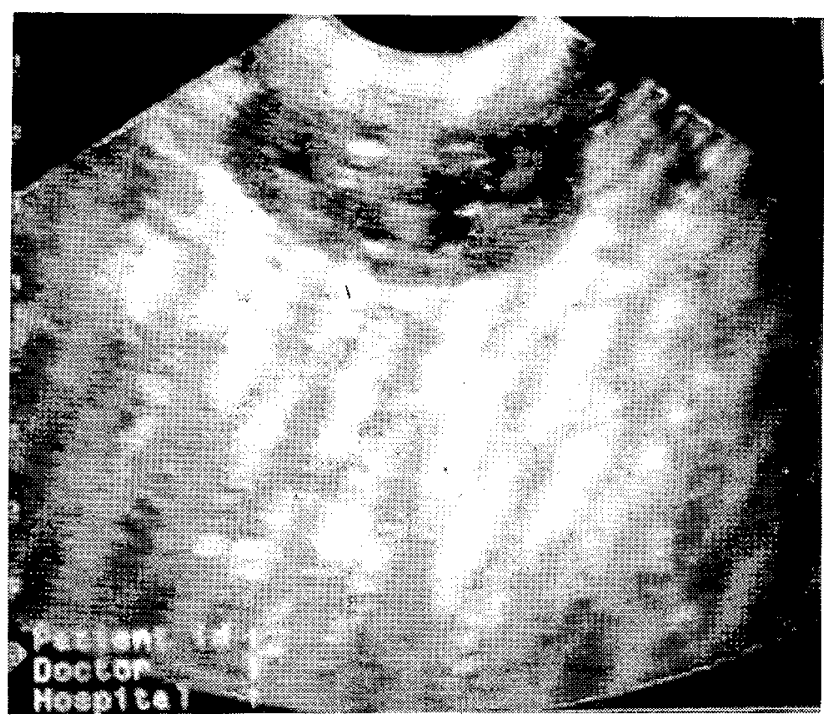

Figure 4. A variable degrees of acoustic enhancements, a cicarly defined internal septa. and thick irregular wall.

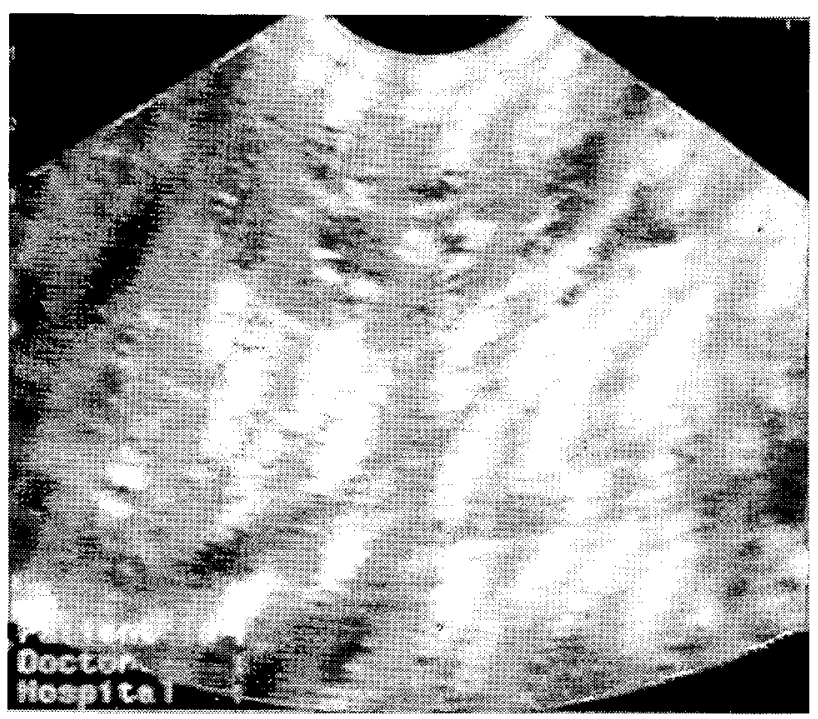

Figure 6. Ultrasonographic appearance of a diffuse increase in echogenicity. Note loss of distinction between cortex and medulla.

7). Dilatation of renal pelvis resulted in a C-shaped echogenicity with a central anechogenic area (Figure 8).

Strongly reflective structures producing deep acoustic shadowing in both kidneys were detected in another two dogs (case no 16,17), and they remained constant even with changes in transducer angulations (Figure 9)

Dorsal ultrasound images of the right kidneys showed a heterogeneous mass, which is located in the cranial pole of the kidney in another dog (case no 18) with hematuria and weight loss (Figure 10A). Oblique ultrasound image of the left kidney showed circular anechoic cavitary lesion and ureteral dilatation (Figure 10B).

Serum concentrations of urea and creatinine were found to be higher in the dogs with kidney problems than 


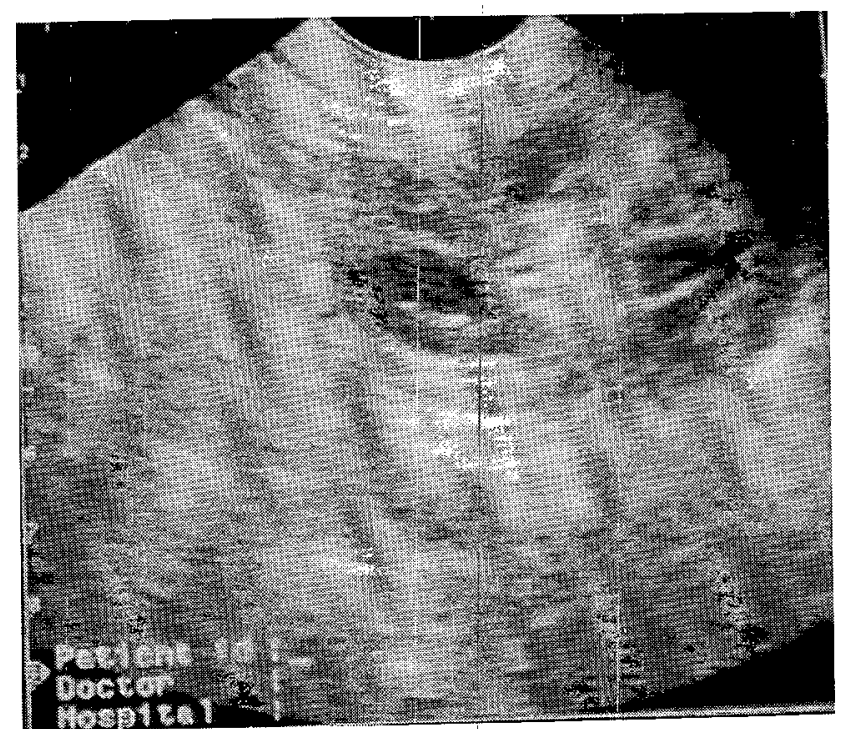

Figure 8. A normal echogenic knot (C-shaped) with a central anechoic area in ultrasonography.

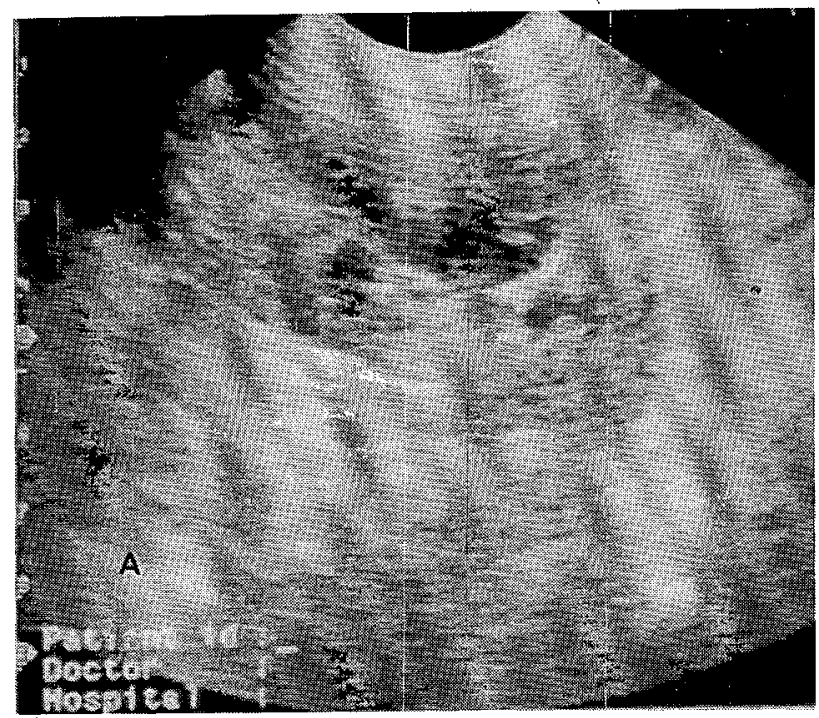

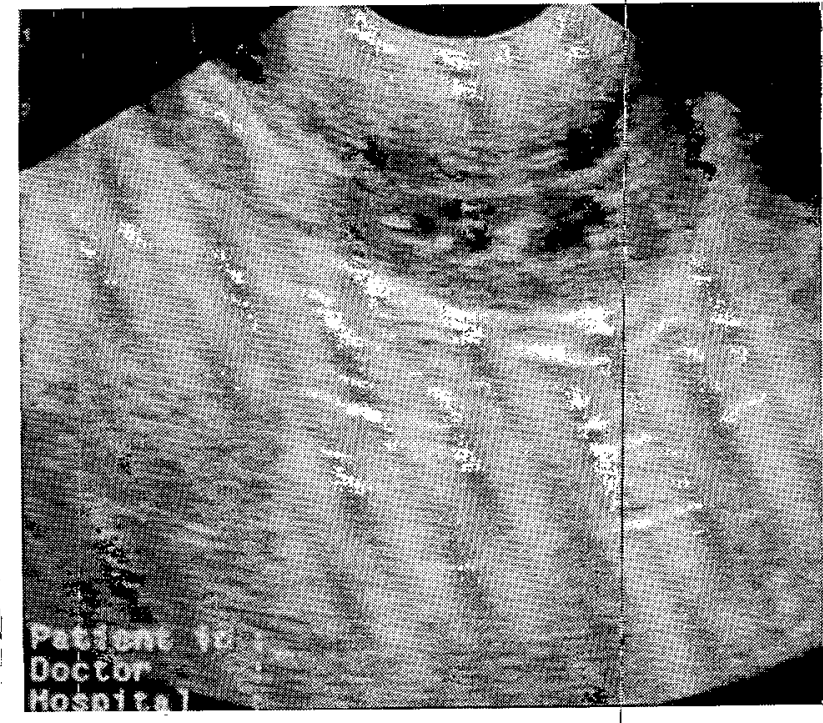

Figure 9. Ultrasonographic view of a reflective structure with acoustic shadowing in a kidney.

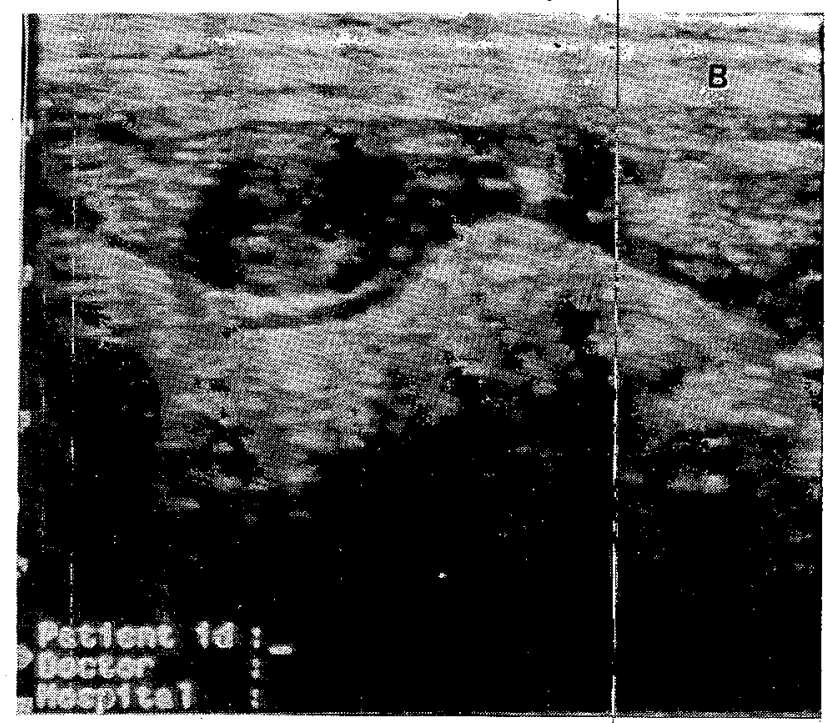

Figure 10. Ultrasonographic appearance of a heterogenous mass located in the cranial pole of the left kidney (A). Oblique ultrasound image of the same kidney with anechoic cavitary lesions and ureteral dilatation (B).

the normal reference ranges (9). Results of some biochemical parameters and creatinine clearance of the 18 dogs were shown in Table 1.

\section{Discussion and Conclusion}

Many pet owners are unaware of the high incidence of kidney diseases in dogs. It is reported that a kidney disease can be the leading cause of non-accidental death in $\operatorname{dogs}(10,16)$, because $20 \%$ of dogs with more than $75 \%$ reduction in kidney function can live without showing any symptoms. Upon further reductions resulting in total kidney failure they are no longer able to remove the waste products and toxins, accumulate in the blood and then show clinical signs of kidney diseases. All breeds of any age can be affected. Therefore, routine ultrasonographic examination should be applied to dogs periodically for early diagnosis of kidney abnormalities $(1,4,18)$.

It is reported that diagnostic ultrasound is an excellent technique for demonstrating the internal architecture. of parenchymal organs and fluid filled structures $(4,13,18)$. It is seen in this study that five mega-hertz $(\mathrm{MHz})$ transducer was appropriate for visualization of urinary tract structures. It produced good resolution with acceptable depth of penetration. It is therefore ideally suited for the investigation of dog urinary tract diseases. It is non-invasive and safe for both patient and operator. Ultrasound is also of more use than intravenous urography when renal function is poor and contrast medium excretion is reduced and is complementary for almost definite diagnosis of kidney abnormalities. In this study, ultrasonography provided 
Table 1. Some biochemical parametres of mongrel dogs with kidney abnormalities.

\begin{tabular}{|c|c|c|c|c|c|c|c|}
\hline $\begin{array}{c}\text { Case } \\
\text { number }\end{array}$ & $\begin{array}{l}\mathrm{BUN} \\
(\mathrm{mg} / \mathrm{dl})\end{array}$ & $\begin{array}{l}\text { Creatinine } \\
(\mathrm{mg} / \mathrm{dl})\end{array}$ & $\begin{array}{l}\text { Total protein } \\
(\mathrm{g} / \mathrm{d} 1)\end{array}$ & $\begin{array}{l}\text { Albumin } \\
(\mathrm{g} / \mathrm{dl})\end{array}$ & $\begin{array}{l}\text { Globulin } \\
(\mathrm{g} / \mathrm{dl})\end{array}$ & $\begin{array}{l}\text { Phosphate } \\
\text { (P) (mg/dl) }\end{array}$ & $\begin{array}{l}\text { Creatinine clearance } \\
\mathrm{ml} / \mathrm{min}\end{array}$ \\
\hline 1 & 113 & 21.6 & 9.3 & 2.9 & 6.4 & 6.4 & 29.4 \\
\hline 2 & 37 & 4.1 & 5.6 & 2.4 & 3.2 & 3.1 & 6.42 \\
\hline 3 & 42 & 13.7 & 10.1 & 2.9 & 7.2 & 6 & 24.7 \\
\hline 4 & 35 & 2.8 & 5.9 & 2.4 & 3.5 & 3.8 & 4.5 \\
\hline 5 & 44 & 10.5 & 9.1 & 2.9 & 6.2 & 5.3 & 18.4 \\
\hline 6 & 41 & 4.4 & 8.8 & 2.9 & 5,9 & 6.2 & 6.4 \\
\hline 7 & 31 & 6.1 & 6.6 & 2.2 & 4.4 & 6.3 & 10.7 \\
\hline 8 & 37 & 7.8 & 7.9 & 2.8 & 5.1 & 5.3 & 9.2 \\
\hline 9 & 80 & 17.2 & 10.6 & 3.2 & 7.4 & 4.1 & 26.4 \\
\hline 10 & 52 & 7.3 & 7.6 & 2.7 & 4.9 & 6.4 & 11.2 \\
\hline 11 & 22 & 3.3 & 4.5 & 2.3 & 2.2 & 11.7 & 5.6 \\
\hline 12 & 20 & 3.7 & 6.1 & 2.7 & 3.4 & 8.5 & 6.8 \\
\hline 13 & 23 & 4.2 & 5.1 & 2.5 & 2.6 & 7.9 & 7.9 \\
\hline 14 & 36 & 6.1 & 7.6 & 2.7 & 4.9 & 5.5 & 10.9 \\
\hline 15 & 18 & 4.4 & 7.4 & 3 & 4.4 & 6.3 & 7.1 \\
\hline 16 & 61 & 9.2 & 9.6 & 3 & 6.6 & 6.1 & 14.4 \\
\hline 17 & 22 & 5.2 & 10.6 & 2.5 & 8.1 & 4.7 & 7.6 \\
\hline 18 & 33 & 5.5 & 9.7 & 3.1 & 6.6 & 6.5 & 7.2 \\
\hline$X \pm S x$ & $41.5 \pm 5.5$ & $7.6 \pm 1.2$ & $7.8 \pm 0.4$ & $2.7 \pm 0.1$ & $5.1 \pm 0.4$ & $6.1 \pm 0.4$ & $11.9 \pm 1.8$ \\
\hline
\end{tabular}

useful information about the internal architecture of the kidneys with focal lesions. Although it is difficult to visualize the normal canine ureters ultrasonographically, ureteral dilatations were able to be detected along with various abnormalities in two dogs with dilated anechoic pelvis in this study. Therefore, there was consistency with previous reports $(4,10,13)$.

Increased cortical echogenicity has been shown to correlate with renal diseases of many etiologies, but it is generally considered as nonspecific $(1,4,16)$. Therefore, BUN and creatinine levels, which are two most significant parameters for diagnosis of kidney abnomalities, were measured in this study. Creatinine is thought to be a more reliable indicator of kidney function, as it well shows that the kidneys are filtering out the toxins, and is less dependent on dietary factors and hydration status of the dog. Serum creatinine is freely filtered in the glomeruli and there is normally $10-40 \%$ excretion in the tubules $(5,8,12)$. In the study presented here, serum creatinine and urea nitrogen values were high, implying renal function disorders and consistent with diagnosis by ultrasonography. For this reason, it could be suggested that high serum creatinine and urea nitrogen values may be indexes for the poor glomerular filtration rate in dogs.

Phosphate is a bone mineral, which is freely filtered through the glomerulus and reabsorbed in the proximal tubules, but excess amounts are actively secreted to the urine. The phosphate concentration in serum increases in renal insufficiency due to intestinal over absorption of phosphate and decreased secretion in the tubules $(3,17)$. In this study, serum phosphate level was higher than the normal physiological reference range in the animals with kidney abnormalities, indicating that there is consistency with the previous reports.

The 24-h period of urine collection for measuring creatinine clearance, being a time-consuming procedure may be impractical for day-to-day monitoring of renal function $(3,5,8,12)$. We, therefore, believe that measurement of creatinine clearance using the Cockroft-Gault equation is very easy with sufficient accuracy, if the dog's weight and age are known.

In conclusion, the incidence of kidney problems was found $45 \%$ in mongrel dogs in the present study. Convincing evidence presented here suggest that dogs should be regularly checked for diagnosis of possible kidney abnormalities using ultrasonography, laboratory parameters, including urea, creatinine, phosphate, and creatinine clearance.

\section{References}

1. Bahr A, Wrigley R, Salman M (2000): Quantitative evaluation of imagent as an abdominal ultrasound contrast medium in dogs. Vet Radiol Ultrasound, 41, 50-55.

2. Barlough JE, Osborne CA, Steven JB (1981): Canine and feline urinalysis: Value of macroscopic and microscopic examinations. JAVMA, 178, 61-67.

3. Barsanti JA, Finco DR (1979): Laboratory findings in urinary tract infections. Vet Clin Nort Am, 9, 729-735.

4. Cartee RE, Selcer BA, Patton CS (1980). Ultrasonographic diagnosis of renal disease in small animals. J Am Vet Med Assoc, 76, 426-430.

5. Cockcroft DW, Gault MH (1976): Prediction of creatinine clearance from serum creatinine. Nephron, 16, 31 41 . 
6. Cowgill LD, Spangler WL (1981): Renal insufficiency in geriatric dogs. Vet Clin North Am Small Anim Pract, 11, 727-748. 7. Finco DR, Crowell WA, Barsanti JA (1985): Effects of three diets on dogs with induced chronic renal failure. Am J Vet Res, 46, 646-653.

8. Herget-Rosenthal S, Kribben A, Pietruck F, Ross B, Philhipp T (1999): Two by two hour creatinine clearancerepeatable and valid. Clin Nephrol, 51, 348-354.

9. Kaneko JJ, Harvey JW, Bruss ML (1997): Clinical Biochemistry of Domestic Animals. Academic Press, London.

10. Kruger JM, Osborne CA, Nachreiner RF, Refsal KR (1996): Hypercalcemia and renal failure. Etiology, pathophysiology, diagnosis, and treatment. Vet Clin North Am Small Anim Pract, 26, 1417-1445.

11. Lamb CR (1998): Ultrasonography of the ureters. Vet Clin North Am Small Anim Pract, 28, 823-848.

12. Mcligeyo SO (1993): Calculation of creatinine clearance fiom plasma clearance. E Afr Med J, 70, 3-5.

13. Miles K (1997): Imaging abdominal masses. Vet Clin North Am Small Anim Pract, 27, 1403-1431.

14. Ruiz de Gopegui R, Espada Y, Majo N (1999): Bilateral hydroureter and hydronephrosis in a nine-year-old female German shepherd dog. J Small Anim Prac, 40, 224-226.
15. Seeds JW (1998): Borderline genitourinary tract abnormalities. Semin Ultrasound CT MR, 19, 347-354.

16. Uechi $M$, Nogami $Y$, Terui $H$, Nakayama $T$, Ishikawa R, Wakao Y, Takahashi M (1994): Evaluation of urinary enzymes in dogs with early renal disorder. J Vet Med Sci, 56, 555-556.

17. Verbeek XA, Willigers JM, Prinzen FW, Peschar M, Ledoux LA, Hoeks AP (2001): High-resolution functional imaging with ultrasound contrast agents based on RF processing in an in vivo kidney experiment. Ultrasound Med Biol, 27, 223-233.

18. Watson AD, McDonald PJ (1981): Comparison of several laboratory tests for quantifying azotaemia in dogs. Aust Vet J, 57, 407-410.

Geliş tarihi: 16.4.2002 / Kabul tarihi: 13.5.2002

Correspondence address:

Yrd. Doç. Dr. Ramazan Gönenci

Mustafa Kemal Üniversitesi

Veteriner Fakültesi

Cerrahi Anabilim Dalt

31040 Antakya/Hatay 